$$
\begin{gathered}
\text { 부비동 모형에서 하비갑개의 구조적 변화와 비중격의 } \\
\text { 천공이 상악동 환기에 미치는 효과 } \\
{\text { 동아대학교 의과대학 이비인후과학교실, }{ }^{1} \text { 의공학교실 }}^{2} \\
\text { 정용수 }^{1} \cdot \text { 강명구 }^{1} \cdot \text { 김동영 }^{1} \cdot \text { 정인호 }^{1} \cdot{\text { 김 } \text { 재룡 }^{1} \text {. 이태훈 }}^{1} \text { 정동근 }
\end{gathered}
$$

\title{
The Effects of the Structural Changes of Inferior Turbinate and Septal Perforation on Maxillary Sinus Ventilation in Model Experiment
}

\author{
Yong-Soo Jung, MD ${ }^{1}$, Myung-Koo Kang, $\mathrm{MD}^{1}$, Dong-Young Kim $\mathrm{MD}^{1}$, In-Ho Jung, $\mathrm{MD}^{1}$, \\ Jae-Ryong Kim, $\mathrm{MD}^{1}$, Tae-Hoon Lee, $\mathrm{MD}^{1}$ and Dong-Keon Jung, $\mathrm{MD}^{2}$ \\ ${ }^{1}$ Department of Otolaryngology-Head and Neck Surgery and ${ }^{2}$ Medical engineering, \\ College of Medicine, Dong-A University, Busan, Korea
}

\begin{abstract}
-ABSTRACT -
Background and Objectives : Inferior turbinectomy has been known to have the possibility of inducing sinusitis. The perforation on septum occurs mostly by septal surgery, and its effect on the ventilation of sinus has not been known. The aim of this study is to measure the changes of maxillary sinus ventilation in conditions of inferior turbinate hypertrophy, inferior turbinectomy or septal perforation. Materials and Methods : From a healthy volunteer with no evidence of sinonasal pathology, one millimeter-thickness axial images of computed tomogram of paranasal sinuses were obtained. Margins between soft tissue and air density in each images were expressed with lines using computer programs, and one millimeter-thickness acrylic plates were cut according to these lines with computerized laser cutting system. They were attached sequentially to make a complete model. The conditions of inferior turbinectomy or septal perforation were expressed with a drill, and the hypertrophy of inferior turbinates was made with silicone. It was fitted with pressure sensors in left nasal cavity, maxillary, sphenoid and frontal sinuses, and with a sensor for oxygen concentration in left maxillary sinus. The pressure changes of each sinonasal cavities and the changes of the oxygen concentration in left maxillary sinus were measured during respiration with 600 milliliter tidal volume and at the rate of 15 times per minute. Results : The alternation of positive and negative pressures was observed according to respiration in the sinonasal cavities. The differences between highest and lowest pressures were increased in the model representing inferior turbinate hypertrophy, and diminished in the models representing inferior turbinectomy and septal perforation. And the times required for the decrease in oxygen concentration were increased in the models of inferior turbinectomy and septal perforation. Conclusion : Extensive resection of inferior turbinate causes the decrease of maxillary sinus ventilation, and it is strongly suggested that septal perforation can reduce the sinus ventilation. This model study is helpful in understanding the influences of the structural changes in sinonasal cavities upon the ventilation of sinuses. (J Clinical Otolaryngol 2003;14:92-99)
\end{abstract}

KEY WORDS : Paranasal sinus $\cdot$ Ventilation $\cdot$ Model $\cdot$ Inferior turbinectomy $\cdot$ Septal perforation.

논문접수일 : 2003년 3월 28일

심사완료일 : 2003년 5월 21일

교신저자 : 강명구, 602- 715 부산광역시 서구 동대신동 3- 1 동아대학교 의과대학 이비인후과학교실

전화 : (051) 240- 5428. 전송 : (051) 253-0712 E- mail : jrkim53@ hanmail.net 
정용수 외 : 부비동 모형에서 하비갑개의 구조적 변화와 비중격의 천공이 상악동 환기에 미치는 효과

부비동염은 부비동 점막의 염증성 질환으로, 부비동 의 자연개구부를 통한 환기, 점막섬모운동(mucociliary action), 점막을 통한 산소교환, 점막내의 혈액공급 등의 정상적인 생리 작용이 방해되는 경우 발생하게 된다. ${ }^{1)}$ 이 중 부비동 자연개구부의 폐쇄로 인한 환기의 장애는 부비동염의 발생에 있어 가장 중요한 요인이며,2) 자연개 구부의 크기 외에도 부비동의 환기는 비강의 크기와 모 양, 비강내 기류, 부비동의 크기, 점막을 통한 가스의 흡 수 등과 같은 다양한 인자에 의해 영향을 받게 된다. ${ }^{3)}$

하비갑개의 비후는 비중격 만곡증과 함께 비폐색의 가 장 흔한 원인이다. 하비갑개 비후에 대한 치료로 시행되 는 하비갑개 절제술은 비폐색의 해소에 우수한 결과를 나타낸다는 보고 ${ }^{4}$ 가 있는 반면에, 과도한 절제는 비강의 정상적인 기류나 점액섬모운동을 방해한다고 알려져 있 다. ${ }^{5)}$ 1998년 Berenholz 등은 하비갑개 절제술 후 많은 환자에서 부비동염을 암시하는 증상이 발현하였고, 술전 각 부비동이 정상이었던 환자 중 $31 \%$ 에서는 수개월 후 전산화 단층촬영상 상악동 및 사골동에 중등도 이상의 혼 탁이 발견되었다고 하였다. ${ }^{6)}$ 그들은 부비동염이 유발되 는 원인이 하비갑개의 상향골절시 발생하는 중비도의 협 착 때문이라고 하여 하비갑개 절제술 후 초래된 상악동 염의 원인을 공기역학적 분석보다는 단지 해부학적 원 인으로 찾고자 하였다.

비폐색의 해소를 위해 흔히 시행되는 수술로는 하비 갑개 수술 이외에도 비중격 수술이 있는데, 비중격 천공 의 대부분은 비중격 수술에 의해 발생한다. 비중격 천공 은 비폐색, 건조감, 재발성 비출혈, 가피 형성 등의 증상 을 나타내게 되는데, 그 중 건조감이나 가피 형성은 점막 의 소실로 인한 습도의 감소가 주된 원인으로 보인다. ${ }^{7)}$ 그러나 천공이 부비동, 특히 상악동의 환기에 어떠한 영 향을 미치는 지는 알려져 있지 않다.

부비동 환기에 대한 연구는 많은 시도가 이루어져 왔 지만, 비강 및 부비동의 복잡한 해부학적 구조와 비점막 의 지속적인 생리적 변화로 인해 부비동 환기에 대한 연구 는 현재까지도 객관적이고 정량적인 방법이 확립되어 있지 않다.

본 연구에서는 객관적이고 재현 가능한 방법으로 실험 하기 위해, 전산화단층촬영을 이용한 바. 부비동 모형을 제작하여 하비갑개의 비후나 절제술, 그리고 비중격의 천
공 상태 등 비강 내의 구조적 변화가 상악동 환기에 미 치는 영향을 알아보고자 하였다.

\section{대상 및 방법}

\section{모형의 제작}

비과적 증상이 없으며, 이학적 검사 및 방사선학적 소 견에서 비. 부비동 질환이 없는 키 $172 \mathrm{~cm}$, 체중 $67 \mathrm{~kg}$ 의 31세 성인 남자를 지원자로 하여 전산화단층촬영(Somatomplus, Siemens, Germany)을 하였다. 전두동 상 연으로부터 상악동 하연까지를 두께 $1 \mathrm{~mm}$, field 크기 $14 \times 14 \mathrm{~cm}$, matrix 512×512로 하여 축상면(axial plane)으로 촬영을 하여 얻어진 영상들을 컴퓨터에 입력 하였다. 영상들의 골조직을 포함한 연부조직 음영과 공기 음영 사이의 경계를 A dobe Photoshop(version 4.0.1K, Adobe Systems Inc., California) 프로그램을 이용하 여 변연을 표현한 후 부비동 자연공을 추적 표시하였고, A utocad R13(Autodesk Inc., California) 프로그램으로 선형 정보를 위치 정보로 변환시킨 후 컴퓨터에 연결된 레이저 절단기(NHBM, Hankwang Inc., Korea) 로 1 $\mathrm{mm}$ 두께의 투명 아크릴 판을 절단하였다. 아크릴 판은 두 벌을 만들었고, 동일한 모형에서 구조적 변화를 용이 하게 주기 위해 한 벌은 비중격 천공을 만들 위치의 상 하로 나누어 상측의 판들과 하측의 판들을 따로 접착하 였고, 다른 한 벌은 하비갑개 높이를 삼등분한 위치를 중 심으로 나누어 접착하였다(Fig. 1). 이등분 또는 삼등분 된 모형의 내부에 하비갑개의 비후를 표현하는 경우는 실리콘을 이용하였으며, 하비갑개가 비중격이나 비강저, 그리고 비강의 외벽으로부터 각각 $1 \mathrm{~mm}$ 의 간격을 갖게 실리콘을 부착하였다. 하비갑개의 절제술 상태는 드릴로 아크릴판을 절단하여 제작하였으며, 반절제술은 하비갑 개 용적의 $50 \%$, 전절제술은 하비갑개 용적의 $100 \%$ 를 제 거하는 것으로 하였다. 또한 비중격 천공 모형에서는 천 공의 중심이 외비공으로부터 $2 \mathrm{~cm}$ 후방, 비강저로부터 $1.5 \mathrm{~cm}$ 상방에 위치하도록 하고 드릴을 이용하여 직경 $5 \mathrm{~mm}$, 실험 후반에는 $15 \mathrm{~mm}$ 가 되게 천공을 만들었다 (Fig. 2). 그 후 나누어져 있는 부분의 양면을 실리콘(KE45, Shin- Etsu Silicone Korea Co., Ltd, Korea) 으로 바 른 후 C자형 조임쇠로 압력을 가해 밀봉되게 하였다. 
모형의 하부에서 좌측 하비도 후단과 좌측 상악동으 로 직경 $2 \mathrm{~mm}$ 의 검출구를 직각으로 뜷었고, 모형의 상 부에서 좌측 전두동과 접형동에 동일한 직경의 검출구를

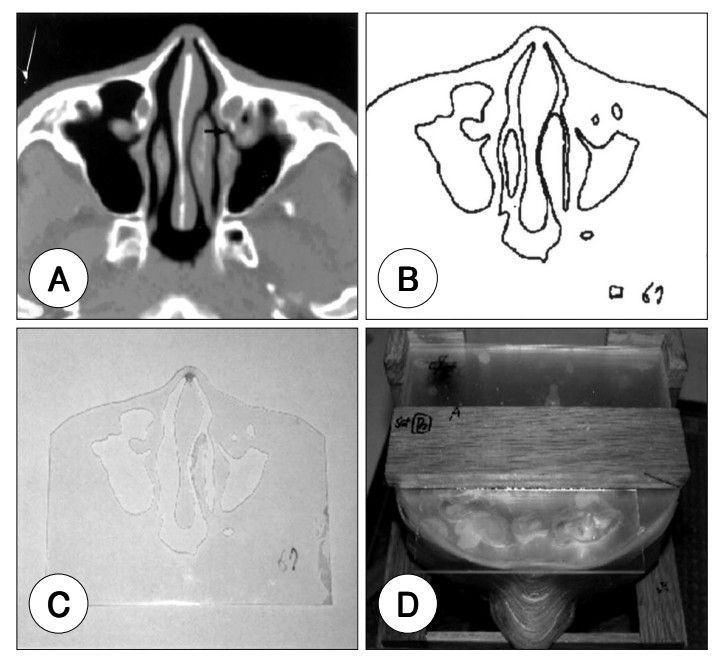

Fig. 1. Process of construction for the sinonasal model. A : Axial image of the paranasal sinus $C T$ at the level of natural ostium (arrow) of maxillary sinus. B : Marginal line between soft tissue and air density area of $A$. C : An one millimeter-thickness acrylic plate cut with laser beam according to the line of B. D : Acrylic plates attached each other sequentially with acrylic resin.
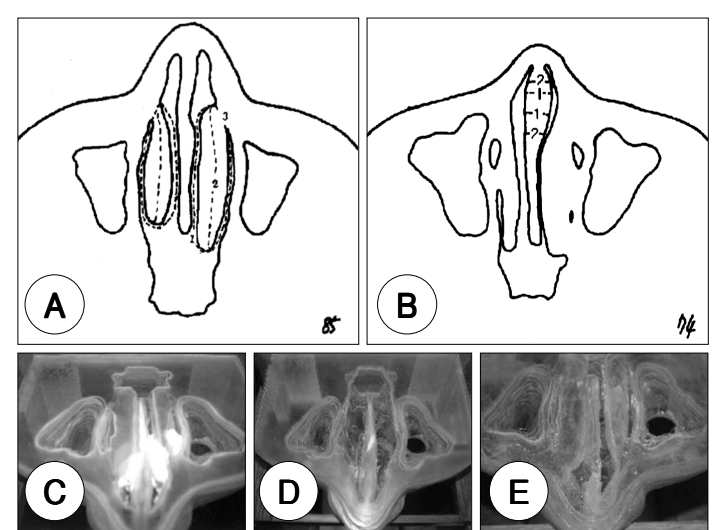

Fig. 2. Expression of hypertrophy of both inferior turbinates, half and total volumetric resection of both inferior turbinates, and $5 \mathrm{~mm}$ and $15 \mathrm{~mm}$ perforation of septum. A : Dashed line 1 represents the hypertrophied both inferior turbinates. Dashed line 2 and 3 represent the half and totally resected both inferior turbinates, respectively. B : Dashed line 1 and 2 represents the 5 $\mathrm{mm}$ and $15 \mathrm{~mm}$ perforation of the nasal septum, respectively. $C$ : Silicone attached to both inferior turbinates to express hypertrophy of the inferior turbinate. $D$ : Totally resected both inferior turbinates with a drill. E : Septal perforation cut with a drill.
마찬가지로 직각으로 뜷어 압력 감지장치(Deltran II disposable pressure transducer, Utah medical products Inc., Utah)를 설치하였다. 또한 좌측 상악동의 하단부에는 직경 $15.8 \mathrm{~mm}$ 의 나사 구멍을 뜷은 후 산소 농도 감지장치(Class R- 17Med, T eledyne A naly tical Instruments, California) 를 밀폐되도록 설치하였으며, 비인두에는 파형도관(corrugated tube)을 연결하였다 (Fig. 3).

\section{비강과 부비동의 압력 측정}

정상 모형에서는 상악동, 전두동, 접형동의 검출구를 폐쇄한 후 비인두에 연결된 파형도관(corrugated tube) 을 통해 폐기능 검사상 1 회 호흡량이 $600 \mathrm{~mL}$ 인 지원 자가 호흡을 하였다. 호흡은 안정상태에서 분당 15회로 20 회 실시하였다. 비강과 연결된 검출구에 압력 감지장 치를 연결하여 압력 변화를 측정하였고, 휴식시간을 가 지면서 3회 반복하여 측정하였다. 각 부비동의 압력 변화 측정도 동일한 방법으로 시행하였다. 압력 감지장치의 전기신호는 Bridge- Amp(Sarotech, Korea) 와 데이터 획득 시스템(P400, Sarotech, Korea)으로 증폭 및 디 지털 신호로 변환하여 개인용 컴퓨터에 연결하였고, 컴 퓨터 프로그램(Phy sioL ab version 2.0, 동아대학교 의 과학 연구소, Korea) 을 통해 그래프로 정량화하였다. 압 력 파형 주기는 수동적으로 판독하여 최고 양압과 최저 음압을 검출하였다. 하비갑개의 비후나 절제술, 비중격 의 천공 모형에서도 동일한 방법으로 호흡에 따른 비강 의 압력변화를 측정하였다.

\section{상악동 환기의 측정}

산소농도 감지장치를 산소농도 측정기(MiniOX I oxygen analyzer, MSA medical products, Pittsburgh)에

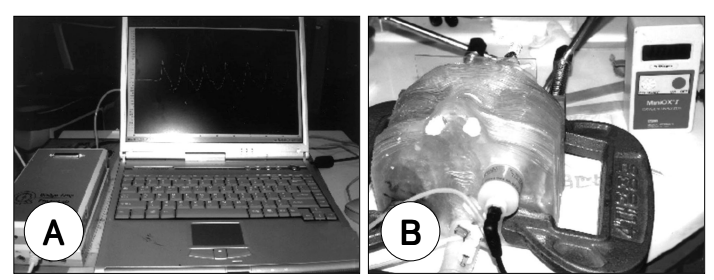

Fig. 3. Equipments for measurement of pressure in the nasal cavity, maxillary, frontal, and sphenoid sinus ( A) and oxygen concentration in the maxillary sinus ( $B$ ). 
연결하여 전기신호가 증폭, 변환 과정 후 액정화면에 수 치로 표현되도록 장치하였다(Fig. 3). 그후 상악동의 압 력 검출구를 통해 $100 \%$ 산소를 주입하여 산소농도가 99\% 이상에 이른 후, 약 1분 정도 충분히 관류시킨 다음 검출구를 폐쇄하였다. 이후 파형 도관을 통해 호흡을 시 작하여 산소농도가 $90 \%$ 에 도달하는 시점부터 $10 \%$ 단위 로 농도가 감소할 때마다 소요시간을 기록하였고, 최종 적으로 $25 \%$ 까지 감소한 시점까지의 시간을 기록하였다. 환기정도를 대변하는 산소농도의 반감기는 최초 산소농도 가 $100 \%$ 이고 최종농도가 $21 \%$ 에 수렴한다고 가정하고 계산하였다. 호흡횟수를 시간으로 환산한 다음, $21+79$ $(1 / 2)^{\mathrm{t} / \mathrm{t}}$ 식에서 T 을 1에서 100까지 0.1초 단위로 계산 하여 최소오차점의 T 을 반감기( $\left.T_{1 / 2}\right)$ 로 하였다. 이러한 실험을 각 모형별로 20 회씩 시행하여 그 결과를 비교하 였다.

\section{통계 분석}

실험에서 얻은 자료에서 정상 모형과 하비갑개의 비 후 모형, 정상 모형과 하비갑개의 반절제 모형, 그리고 정상 모형과 $5 \mathrm{~mm}$ 크기의 비중격 천공 모형에서의 결과 를 각각 비교 분석하였다. 또한 하비갑개의 반절제 모형 과 전절제 모형, 그리고 $5 \mathrm{~mm}$ 와 $15 \mathrm{~mm}$ 크기의 비중 격 천공 모형에서의 결과도 각각 비교하였다. 호흡에 따 른 압력 변화의 폭은 student t- test를 이용하였고, 상 악동의 환기 즉, 산소농도가 $90 \%$ 에서 $25 \%$ 로 감소하는 데 소요되는 시간과 반감기는 Mann- Whitney U test 를 이용하였다. 모든 통계처리는 SPSS 프로그램(SPSS Inc., Illinois) 을 이용하였고, p- value가 0.05 미만인 경 우를 통계적으로 의미 있는 것으로 분석하였다.

\section{결 과}

비강과 부비동의 압력은 호흡주기와 일치하여 양압과 음압이 교번하였으며, 20 회의 호흡 동안 비교적 일관된 압력곡선을 나타내었다 Fig. 4). 정상 모형의 비강에서

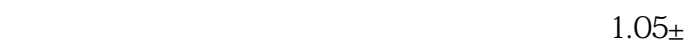
$0.05 \mathrm{mmH}_{2} \mathrm{O}$ 와 - $0.91 \pm 0.10 \mathrm{mmH}_{2} \mathrm{O}$ 이고, 각각의 호 흡에서 최고 양압과 최저 음압의 압력차는 $1.96 \pm 0.11$ $\mathrm{mmH}_{2} \mathrm{O}$ 로 측정되었다. 그리고 각 부비동의 압력차는 상

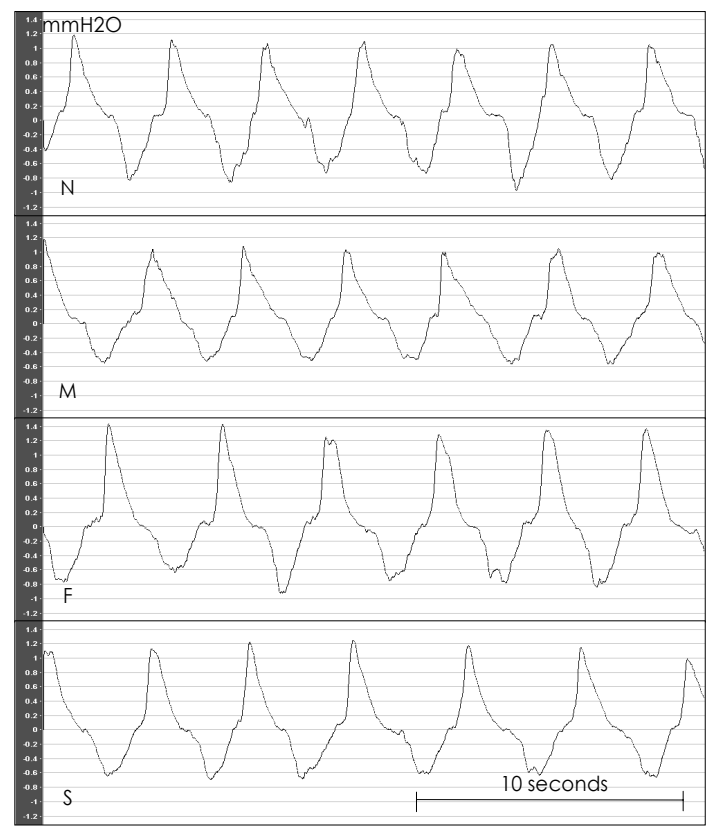

Fig. 4. Tracing of the pressure in the left nasal cavity $(N)$, maxillary $(M)$, frontal $(F)$ and sphenoid sinus $(S)$ in normal model during controlled respiration. * : $\mathrm{p}<0.01$ compared with NL, $\uparrow: P<0.01$ compared with $H R, \ddagger: P<0.01$ compared with SP5.

Table 1. Peak positive pressures (PP), peak negative pressures (PN) and pressure differences (PD) of the left nasal cavity $(N)$, maxillary $(M)$, frontal $(F)$ and sphenoid sinus ( $S$ ) in normal model

\begin{tabular}{crccc}
\hline & $\mathrm{N}$ & $\mathrm{M}$ & $\mathrm{F}$ & $\mathrm{S}$ \\
\hline $\mathrm{PP}$ & $1.05 \pm 0.05$ & $1.01 \pm 0.12$ & $1.36 \pm 0.12$ & $1.18 \pm 0.16$ \\
$\mathrm{PN}$ & $-0.91 \pm 0.10$ & $0.63 \pm 0.08$ & $-0.79 \pm 0.12$ & $0.72 \pm 0.11$ \\
$\mathrm{PD}$ & $1.96 \pm 0.11$ & $1.64 \pm 0.11$ & $2.15 \pm 0.15$ & $1.90 \pm 0.22$ \\
\hline \multicolumn{4}{l}{ The values are presented as mean $\pm \mathrm{SD}\left(\mathrm{mmH}_{2} \mathrm{O}\right)}$.
\end{tabular}

악동에서 $1.64 \pm 0.11 \mathrm{mmH}_{2} \mathrm{O}$, 전두동에서 $2.15 \pm 0.15$ $\mathrm{mmH}_{2} \mathrm{O}$, 그리고 접형동에서 $1.90 \pm 0.22 \mathrm{mmH}_{2} \mathrm{O}$ 로 측 정되어 비강과 각 부비동의 압력은 부위에 따라 다른 분포를 보였다 ( T able 1).

각 조건에서의 비강의 압력차이는 하비갑개의 비후에서

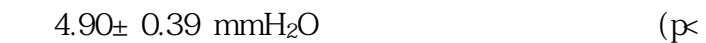
0.01 ), 하비갑개의 반절제에서는 $1.55 \pm 0.16 \mathrm{mmH}_{2} \mathrm{O}$ 로 감소 $(p<0.01)$ 되었다. 하비갑개의 전절제에서는 $0.86 \pm$ $0.07 \mathrm{mmH}_{2} \mathrm{O}$ 로 반절제 상태보다 감소되었다 $(p<0.01)$. 또 한 $5 \mathrm{~mm}$ 크기의 비중격 천공에서도 $1.14 \pm 0.05 \mathrm{mmH}_{2} \mathrm{O}$ 


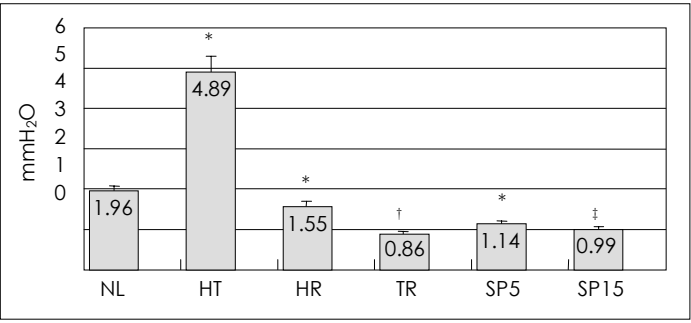

Fig. 5. Pressure differences in the left nasal cavity of the normal ( $\mathrm{NL})$, hypertrophy of both inferior turbinates $(\mathrm{HT})$, half resected state of both inferior turbinates ( $H R)$, totally resected state of both inferior turbinates (TR), 5 $\mathrm{mm}$ perforation of anterior nasal septum (SP5) and 15 $\mathrm{mm}$ perforation of anterior nasal septum (SP15) models.

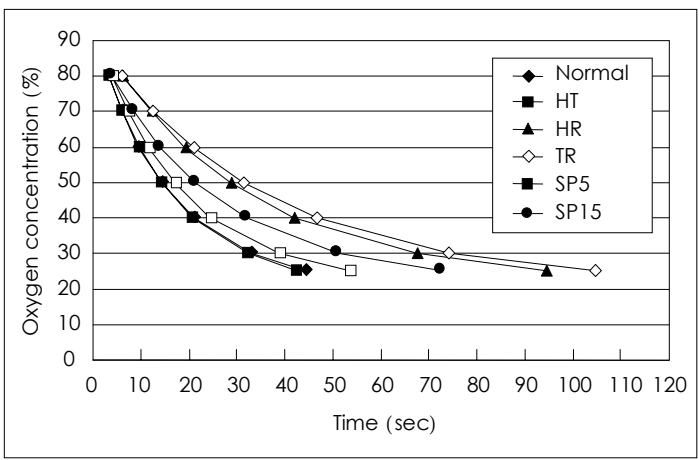

Fig. 6. Oxygen concentration decay curves of the left maxillary sinus of the normal (NL), hypertrophy of both inferior turbinates $(\mathrm{HT})$, half resected state of both inferior turbinates $(H R)$, totally resected state of both inferior turbinates (TR), $5 \mathrm{~mm}$ perforation of anterior nasal septum (SP5) and $15 \mathrm{~mm}$ perforation of anterior nasal septum (SP15) models. Tl/2=21+79(1/2) $t / \mathrm{T}, *: \mathrm{p}=0.015$ compared with $\mathrm{NL}, \dagger: \mathrm{P}<0.01$ compared with $\mathrm{NL}$, $: \mathrm{P}<$ 0.01 compared with HR, $\S: p<0.01$ compared with SP5.

로 정상에 비해 감소하였고( $\mathrm{p}<0.01), 15 \mathrm{~mm}$ 크기의 비중격 천공에서는 $5 \mathrm{~mm}$ 크기의 천공 상태에 비교하여 $1.00 \pm 0.07 \mathrm{mmH}_{2} \mathrm{O}$ 로 감소되었다 $(p<0.01$ ) (Fig. 5).

상악동의 환기 정도는 각 조건에서 20 회의 반복 실험 을 통해 산소농도가 $90 \%$ 에서 $25 \%$ 로 감소할 때까지의 시간을 측정하여 평가하였으며, 산소농도의 반감기도 함께 산출하였다. 정상 모형에서는 산소농도가 $90 \%$ 에서 $25 \%$ 로 감소할 때까지의 시간이 $44.40 \pm 0.77$ 초였고, 하비갑 개의 비후에서는 $42.32 \pm 1.33$ 초로 단축되었다 $(p<0.01)$. 하비갑개의 반절제에서는 $94.28 \pm 0.90$ 초로 연장되었고 $(p<0.01)$, 전절제에서는 $104.68 \pm 1.61$ 초로 반절제 상태

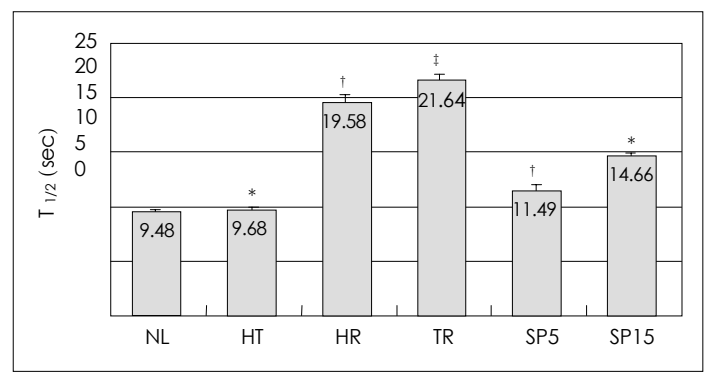

Fig. 7. The half-time of oxygen concentration decay of the left maxillary sinus in the normal (NL), hypertrophy of both inferior turbinates ( $\mathrm{HT}$ ), half resected state of both inferior turbinates (HR), totally resected state of both inferior turbinates (TR), $5 \mathrm{~mm}$ perforation of anterior nasal septum (SP5) and $15 \mathrm{~mm}$ perforation of anterior nasal septum ( SP15) models.

보다 더 연장되었다 $(p<0.01)$. 그리고 $5 \mathrm{~mm}$ 크기의 비중 격 천공에서도 $53.38 \pm 2.75$ 초로 정상 상태에 비해 연 장되었고( $p<0.01), 15 \mathrm{~mm}$ 크기의 비중격 천공에서는 5 $\mathrm{mm}$ 크기의 천공 상태에 비해 $72.60 \pm 0.98$ 초로 더 연 장되었다( $p<0.01$ ) (Fig. 6).

산소농도의 반감기는 정상 모형에서 $9.48 \pm 0.16$ 초였

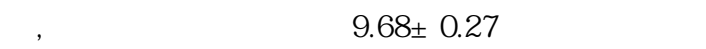
( $p=0.015)$. 하비갑개의 반절제에서도 $19.58 \pm 0.71$ 초로 연장되었고 $(p<0.01)$, 전절제에서는 $21.64 \pm 0.50$ 초로 반절제 상태보다 연장되었다 $p<0.01)$. 그리고 $5 \mathrm{~mm}$ 크 기의 비중격 천공에서도 $11.49 \pm 0.50$ 초로 정상 상태에 비해 연장되었고, $15 \mathrm{~mm}$ 크기의 비중격 천공에서는 5

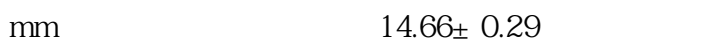
되었다( $p<0.01$ ) (Fig. 7).

\section{고 찰}

부비동의 환기는 점액섬모운동과 함께 비강과 부비동 의 정상적인 생리 기능에 필수적인 요소이다. ${ }^{2)}$ 이는 점막 의 비후, 비용종, 섬모운동 장애, 비중격 만곡 등 다양한 원인에 의해 영향을 받게 된다. 현재까지 부비동 환기에 대한 공기역학적 연구는 모형을 이용하거나 인체를 대 상으로 하여 계속되고 있으나, 아직까지 객관적이고 확립 된 측정법이 없는 실정이다. 이는 바. 부비동의 구조적 복잡성과 지속적인 점막 생리의 변화 등과 같은 제한요 
정용수 외 : 부비동 모형에서 하비갑개의 구조적 변화와 비중격의 천공이 상악동 환기에 미치는 효과

소 때문이라 생각된다.

부비동 환기에 대한 연구는 크게 모형을 이용한 실험 과 인체를 대상으로 한 연구로 나누어 볼 수 있다. 모형 을 이용한 연구는 인체를 대상으로 한 침습적인 방법을 피하고 재현성 있는 결과를 얻기 위해 시도되었고 다양 한 방법이 발표되었다. Nagoshi 등은 사체를 이용한 바 부비동 모형을 제작하여 비인강을 통한 호흡시에 부 비동의 압력변화를 측정하였다. 1993년 Hahn 등 ${ }^{9}$ 은 비 부비동 모형을 제작하는데 최초로 전산화단층촬영 의 영상을 이용하였고 제작된 모형에서 hot film anenometer probe로 기류의 속도를 측정하여 속도 윤곽도를 구한 바 있다. 최근 Paulsson 등 ${ }^{10)}$ 은 음향통기도 검사를 이용한 연속적인 비강의 단면적을 기초자료로 하여 비 강 모형을, $20 \mathrm{~mL}$ 크기의 주사기로 상악동 모형을 만들 어, 두 모형을 연결하여 비강 및 상악동 모형을 만들었 다. 그리고 133- xenon을 이용하여 상악동 자연개구부 의 크기와 비폐색의 부위에 따른 상악동의 환기정도를 평가하였다.

부비동 환기에 대한 인체를 대상으로 한 연구는 초 기에 주로 부비동 내의 압력 측정을 통해 이루어졌다. Wessely ${ }^{11)}$ 는 정상 성인의 상악동을 천자하여 비호흡에 따른 압력변화를 보고하였고, Proetz ${ }^{12)}$ 는 비강과 상악 동 내에서 동시에 압력을 측정한 결과, 호흡 중에 생기는 비강과 상악동 사이의 압력차로 인해 상악동의 자연개 구부를 통한 공기의 흐름이 일어난다고 하였다. Aust와 Drettner ${ }^{13)}$ 등은 feny Ipropanolamin이 상악동 자연공 의 크기 변화에 미치는 효과에 대한 연구에서 하비도를 통 해 상악동내로 2 개의 관을 넣어 한쪽으로 공기를 주입 하여 일정한 압력에 도달하도록 만든 후, 다른 한쪽으로 는 자연개구부를 통한 공기 유출로 인해 상악동 내의 압력 이 감소하는 속도를 측정하여 자연개구부의 환기능을 평가하였다.

Muenbeck과 Rosenberg ${ }^{14)}$ 는 상악동의 압력이 아닌 비강과 상악동의 기류를 측정함으로써 부비동의 환기능을 연구하였다. 기류의 측정은 hot- film anenometer 를 상악 동 내에 삽입시켜 이루어졌으며, 자연개구부 전체 또는 일부의 폐쇄시 상악동에서의 기류 속도가 감소되었음을 보고하였다. Rettinger 등은 133- xenon을 비강에 주입
시킨 후 scintillation camera를 이용하여 호흡에 따른 부비동내 농도의 감소를 측정하는 방법을 사용하였고, ${ }^{15)}$ 그후 133- xenon을 주입한 후 CT 촬영이나 SPECT 촬영을 하는 방법도 이용되었다. ${ }^{16) 17)}$ Xenon- enhanced CT 는 1985년 Kalender 등 ${ }^{18)}$ 에 의해 부비동 환기의 연 구에 처음으로 도입되었다. 이 연구에서 부비동의 환기 속도는 상악동이 가장 빠르며, 다음으로 사골동, 접형동, 전두동의 순이라고 하였다.

한편 1953년 Proetz ${ }^{12)}$ 는 부비동의 완전한 환기는 수 시간에 걸쳐 이루어진다고 보고하였고, Drettner과 $\mathrm{Aust}^{19)}$ 는 산소농도를 측정하는 방법으로 상악동의 환기 에 약 5 분이 걸린다고 하였고, 자연공의 크기가 적을수 록 환기시간이 길어지며, 구강호흡시 비호흡시에 비해 2 배 정도의 환기시간이 걸린다고 하였다.

이상의 여러 연구에서 볼 수 있듯이 부비동의 환기에 대한 많은 연구가 진행되었지만, 정량적이며 재현 가능 한 연구방법은 확립되어 있지 않은 상태이다. 본 연구에 서는 Jeong 등 $^{20)}$ 이 이용한 방법으로 비. 부비동 모형을 제작하고 구조적인 변화를 가하여 실험하였다. 본 연구 결과에서 호흡에 따른 비강과 부비동의 압력변화가 이전 의 인체에서의 연구 결과보다 낮은 것은 비강 점막이 정 상적으로 가지는 점액이나 섬모 등의 저항요소가 배제되 었다는 점과 $2 \mathrm{~mm}$ 직경의 검출구를 통해 외부에서 압 력을 측정하였다는 점이 원인으로 작용했다고 추정된다.

본 실험에서 하비갑개의 비후는 정상 조건에 비해 비 강의 저항을 증가시키지만, 하비갑개 비후 자체만으로는 상악동 환기에 큰 영향을 미치지 않는 것으로 관찰되었다. 그러나 인체에서는 하비갑개의 비후가 있는 경우 대부 분 중비갑개나 다른 부위 점막의 병변을 동반하고, 다른 요소로서 비폐색으로 인한 구호흡으로의 전환도 많을 것 으로 추정되므로 실제 상악동 환기의 정도는 감소하는 경우가 많을 것으로 사료된다.

하비갑개 절제술은 비강의 저항을 감소시키면서 상악 동의 환기도 함께 감소시키는 것으로 나타났고, 상악동 환기의 감소는 절제의 정도가 클수록 현저하였다. 이러 한 결과는 하비갑개의 전절제술이 여러 가지 증상들과 함께 부비동염을 유발할 수 있다는 기존의 보고들 ${ }^{5)}$ 을 뒷받침해준다. 하지만 부비동염을 일으킬 위험을 증가시 
키는 하비갑개 절제의 정도에 대해서는 불분명한 상태 이며, 향후 중비도의 협착, 비점막의 결손 그리고 하비갑개 의 용적 등을 고려한 생리적인 상태에서의 조사가 필요 할 것으로 사료된다.

비중격 천공에서는 현재까지 여러 문헌에서 언급된 비 폐색, 건조감, 재발성 비출혈, 가피 형성 등의 임상 양상 외에도 본 연구에서 처음 제시한 바와 같이 상악동 환기의 감소로 인한 비강 및 부비동 생리의 변화 가능성도 염 두에 두어야 할 것으로 판단되며, 향후 부비동염 발생율 등에 대한 조사가 필요할 것이라 사료된다.

본 모형은 인체에서의 연속적인 해부학적 구조에 비 해 $1 \mathrm{~mm}$ 간격의 계단 구조로 이루어져 있다는 점, 인체 점막의 저항이나 가습 등의 조건을 가할 수 없다는 점, 그리고 정상 성인 한 명을 대상으로 한 모형이라는 점 등에서 제한점을 가진다고 판단된다. 그러나 본 실험의 결과가 비강이나 부비동의 압력 변화나 상악동 환기에 대한 절대적인 측정치를 구하는 목적으로는 사용되기 어렵지만 비강이나 부비동의 구조적인 변회를 추가한 각 조건들에서의 상대적인 측정치의 비교에는 유용하리라 고 생각된다. 향후 비강 및 부비동의 압력 측정을 동시 에 시행하여 호흡에 따른 압력 변화의 양상을 분석하고, 사람의 흡기와 호기를 유사하게 일관적으로 반영하는 호 흡기를 사용함으로써 부비동의 압력 변화와 부비동 환기 의 측정을 보다 객관적이고 정확하게 하는 노력이 필요 할 것으로 사료된다.

\section{결 론}

본 연구에서는 고해상도 전산화단층촬영의 영상을 바 탕으로 비 부비동의 모형을 제작하여 비강의 구조적 변화가 부비동의 환기에 영향을 미치는 것을 확인하였고, 이러한 실물크기의 정교한 비· 부비동 모형은 부비동 환기의 객관적이고 정량적인 연구에 실험적 유용성을 제 시하였다. 본 연구결과는 하비갑개 절제술을 비롯한 비 강의 구조적 변화를 초래하는 수술의 결과와 장기적인 예후에 대한 평가를 위한 정량적인 부비동 환기 연구의 기초자료로 활용될 수 있을 것으로 사료된다.
중심 단어 : 부비동 환기 모형 하비갑개 절제술 비중 격 천공.

\section{REFERENCES}

1) Drettner B, Aust B. Pathophysiology of the paranasal sinuses. Acta Otolaryngol (Stockh) 1997;83:16-9.

2) Pollei SR, Harnsberger HR. The radiologic evaluation of the sinonasal region. Postgrad Radiol 1989;9:242.

3) Proetz AW. Some intimate studies of nasal function: Their bearing on diagnosis and treatment. Ann Otol Rhinol Laryngol 1932;41:125-40.

4) Ophir D, Shapira A, Marshak G. Total inferior turbinectomy for nasal airway obstruction. Arch Otolaryngol 1985; 111:93-5.

5) Simmen D, Scherrer JL, Moe K, Heinz B. A dynamic and direct visualization model for the study of nasal airflow. Arch Otolaryngol Head Neck Surg 1999;125:1015-21.

6) Berenholz L, Kessler A, Sarfati S, Eviatar E, SegalS. $C h$ ronic sinusitis: A sequela of inferior turbinectomy. Am J Rhinol 1998;12:257-61.

7) Lindemann J, Kuhnemann S, Stehmer V, Leiaker R, Rettinger G, Keck T. Temperature and humidity profile of the anterior nasal airways of patients with nasal septal perforation. Rhinology 2001;39:202-6.

8) Nagoshi Y, Usui N, Unoki S, Ishizuka Y, Yamaguchi O. Ventilation of the paranasal cavity. Jibiinkoka 1970;42: 409-19.

9) Hahn I, Scherer PW, Mozell MM. Velocity profiles measured for airflow through a large-scale model of the human nasal cavity. J Appl Physiol 1993;75 (5) :2273-87.

10) Paulsson B, Dolata J, Lindberg S, Ohlin P. Factors influencing 133-xenon washout in a nose-sinus model. Clinical Physiology 2001;21:246-52.

11) Wessely E. Die Druckverh?ltnisse in der Nebenh?len der Nase. Mschr Ohrenheilk 1921;55:1730-6.

12) Proetz AW. Applied physiology of the nose. 2nd ed. St. Louis; Annals Publishing Company;1953.

13) Aust R, Drettner B. The functional size of the human maxillary ostium in vivo. Acta Otolaryngol (Stockh) 1974;78: 432-5.

14) Müsenbeck K, Rosenberg H. Measurement of velocity of air flow in the sinus maxillaris. Rhinol 1979;17:13.

15) Rettinger G, Suess C, Kalender WA. Studies of paranasal sinus ventilation by xenon-enhanced dynamic CT. Rhinology 1986;24:103-12.

16) Paulsson B, Lindberg S, Ohlin P. Washout of 133-xenon as an objective assessment of paranasal sinus ventilation in endoscopic sinus surgery. Ann Otol Rhinol Laryngol 2002; 111:710-7.

17) Marcucci C, Leopold DA, Cullen M, Zinreich SJ, Simon BA. Dynamic assessment of paranasal sinus ventilation using xenon-enhanced computed tomography. Ann Otol Rhinol Laryngol 2001;110:968-75. 
정용수 외 : 부비동 모형에서 하비갑개의 구조적 변화와 비중격의 천공이 상악동 환기에 미치는 효과

18) Kalender WA, Rettinger G, Suss C. Measurement of paranasal sinus ventilation by xenon-enhanced dynamic computed tomography. J Comput Assist Tomogr 1985;5: 678-83.

19) Aust R, Drettner B. Ventilatory studies of the maxillary sinus. Int Rhinol 1971;9:69-78.
20) Jeong YS, Kim SR, Kim DH, Jung DK, Choi SS, Jung IH, et al. A model of human nose and paranasal sinuses for the study of sinus ventilation. Korean J Otolaryngol 1999;42: 1124-8. 